\section{Reflection}

The term reflection has been been used to describe a form of re-entry in a linear bundle in which two regions of excitable tissue are separated by an area of depressed conduction. ${ }^{4}$ During reflection, excitation occurs slowly in one direction along the bundle and is followed by continued propagation and excitation in the opposite direction. One form of reflection may be micro re-entry due to functional longitudinal dissociation within the depressed segment..$^{5-7}$

\section{Parasystole}

An ectopic pacemaker may sometimes be connected to the remainder of the heart through tissue in which there is unidirectional block. Such block prevents the dominant rhythm, usually a sinus rhythm, from entering the region where the ectopic pacemaker is located. As a result, the ectopic pacemaker is not suppressed by the dominant rhythm. Moreover, because the block is unidirectional, impulses generated by the ectopic pacemaker can be conducted out to other regions of the heart provided these regions are not refractory, causing premature beats or even a tachycardia. This kind of rhythm is called parasystole.

\section{Phase 4 block}

An impulse may be blocked if it arrives at a site-eg, in the His bundle or one of the bundle branches-that is partly depolarised during spontaneous phase 4 depolarisation but has not reached threshold. This spontaneous diastolic depolarisation can depolarise the tissue sufficiently to inactivate the fast sodium channels and cause failure of propagation. ${ }^{10}$

Supported in part by grants RO1 HL38408 and RO1 HL31393 and by program project grant HL30557 from the United States Public Health Service, National Institutes of Health, National Heart, Lung, and Blood Institute, Bethesda, Maryland, and by a grant from the Wuliger Foundation.

\section{REFERENCES}

1. Hoffman BF, Cranefield PF. The physiological basis of cardiac arrhythmias. Am 7 Med 1964; 37: 670-84.

2. Waldo AL, Wit AL. Mechanism of cardiac arrhythmias and conduction disturbances. In: Schlant RC, Alexander RW, eds. Hurst's the heart. 8th ed. New York: McGraw-Hill (in press).

3. Wit AL, Janse MJJ. The ventricular arrhythmias of ischemia and infarction: electrophysiological mechanisms. Mount Kisko, NY: Futura, 1992.

4. Vassalle $M$. The relationship among cardiac pacemakers: overdrive suppression. Circ Res 1977; 41: $269-77$.

5. Cranefield PF, Aronson RS. Cardiac arrhythmias: the role of triggered activity and other mechanisms. Mount Kisco, NY: Futura, 1988.

6. Hoffman BF, Dangman KH. Are arrhythmias caused by automatic impulse generation? In: Paes de Carvalho A, Hoffman BF Lieberman $M$, eds. Normal and abnormal conduction in the heart. Mount Kisco, NY: Futura, 1982: 429-48.

7. Jackman WM, Friday KS, Anderson JL, Aliot EM, Clark M, Lazzara R. The long QT syndrome: a critical review, new clinical observation and a unifying hypothesis. Prog Cardiovasc Dis 1989; 31: 115-72.

8. Wit AL, Cranefield PF. Reentrant excitation as a cause of cardiac arrhythmias. Am $\mathcal{J}$ Physiol 1978; 235 : H1-17.

9. Hoffman BF, Rosen MR. Cellular mechanisms for cardiac arrhythmias Circ Res 1981; 49: 1-15.

10. Singer DH, Lazzara $R$, Hoffman BF. Interrelationships between automaticity and conduction in Purkinje fibres. Circ Res 1967; 21 537-58.

\title{
Are war and public health compatible?
}

\section{Michael J. ToOle Steven Galson William Brady}

A public health assessment during March, 1993, in Bosnia-Herzegovina and in the areas of Serbia and Montenegro hosting Bosnian refugees, revealed extensive disruption to basic health services, displacement of more than 1 million Bosnians, severe food shortages in Muslim enclaves in eastern Bosnia, and widespread destruction of public water and sanitation systems. War-related violence remains the most important public health risk; civilians on all sides of the conflict have been intentional targets of physical and sexual violence. The impact of the war on the health status of the population has been difficult to document; however, in the central Bosnian province of Zenica, perinatal and child mortality rates have increased twofold since 1991. The crude death rate in one Muslim enclave between April, 1992, and March, 1993, was four times the pre-war rate. Prevalence rates of severe malnutrition among both adults and children in central Bosnia have been increasing since November, 1992. Major epidemics of communicable diseases have not been reported; however, the risk may increase during the summer of 1993 when the effects of disrupted water and sanitation systems are more likely to promote enteric disease transmission. Economic sanctions against Serbia and Montenegro may lead to declining health care standards in those republics if basic medical supplies cannot effectively be exempted.

Lancet 1993; 341: 1193-96.

\section{Introduction}

We describe here a public health needs assessment in March, 1993, in Bosnia-Herzegovina. The assessment (sponsored by the USAID Office of Foreign Disaster Assistance) consisted of visits to health facilities, reviews of records, interviews, and observations of affected communities in extensive areas of Muslim-controlled central Bosnia, Serb-controlled eastern Bosnia, a rural Muslim enclave in eastern Bosnia, and areas of Serbia and Montenegro hosting large numbers of Bosnian refugees (fig 1). Limitations included lack of population-based health data, restricted access to certain areas, and insufficient opportunities to collect primary data.

ADDRESS: Centers for Disease Control and Prevention, Atlanta, Georgia, USA (M. J. Toole, MD, S. Galson, MD, W. Brady, MPH). Correspondence to Dr Michael J. Toole, International Health Program Office, Centers for Disease Control and Prevention, Atlanta, Georgia 30333, USA. 


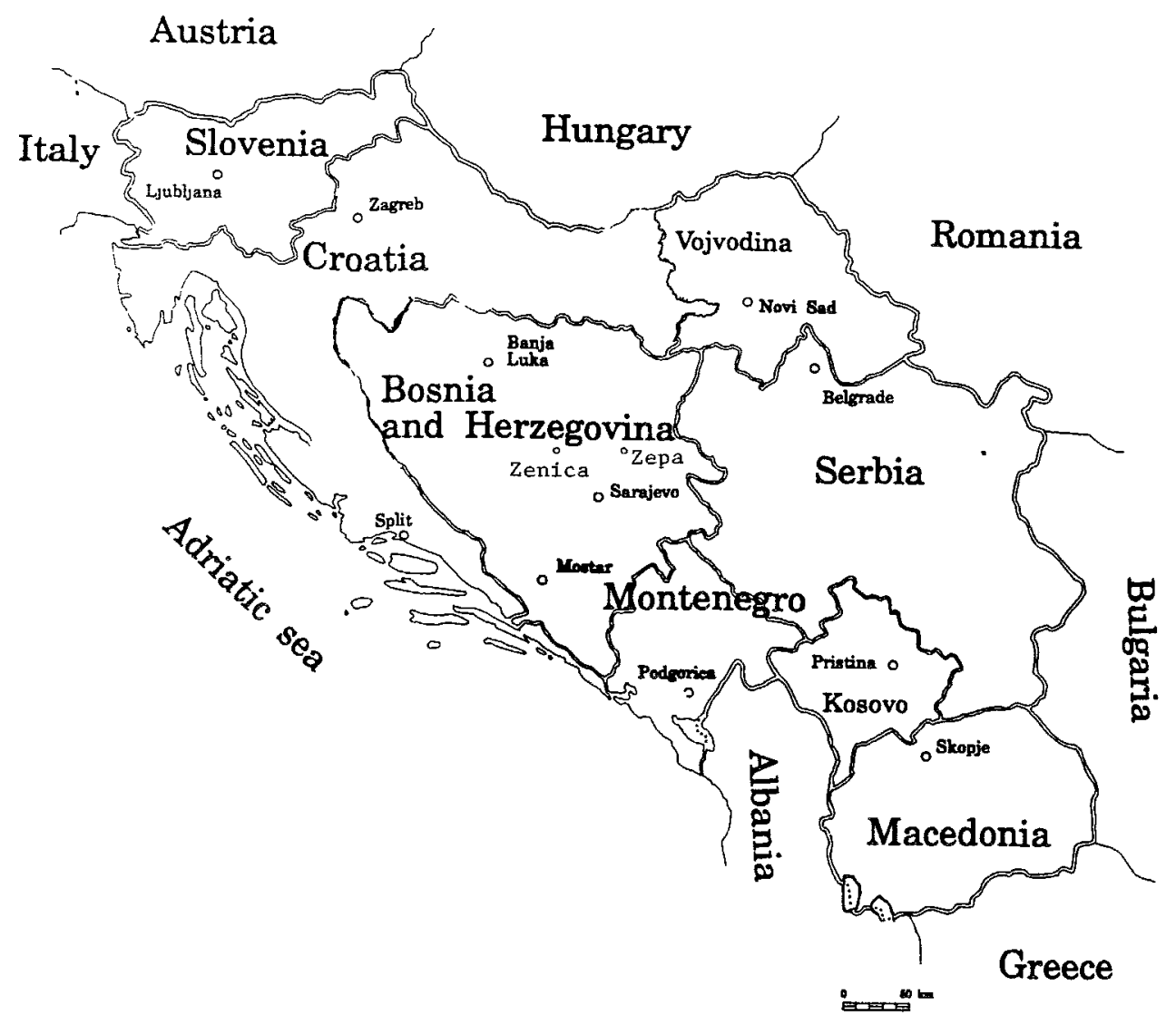

Fig 1-Republics of former Yugoslavia.

On May 1, 1992, Serbian forces began shelling Sarajevo, the capital of the newly declared republic of BosniaHerzegovina. Since then, a violent conflict among Muslim, Croatian, and Serbian forces has divided the country into a patchwork of ethnoreligious ministates. The pre-war population of Bosnia-Herzegovina was approximately 4.5 million, of whom $44 \%$ were Muslims, $31 \%$ Serbs, $17 \%$ Croats, and the remainder either mixed or other ethnicity. By March, 1993, about $70 \%$ of the territory of BosniaHerzegovina had been occupied by Serbian forces.

The conflict in Bosnia-Herzegovina has direct and indirect effects on the health of civilians. According to US government estimates, at least 17000 people have been killed; ${ }^{1}$ the Bosnian government places the death toll at over 150000 . Civilian populations in besieged towns and refugees have been targets of military firepower. For example, Muslims in the enclave of Zepa were shelled immediately after every American airdrop of food in early March, 1993; five villagers were killed on the morning of our assessment visit. In addition, reports have documented extensive sexual violence against civilians on all sides. ${ }^{2}$ Indirect effects of the war have resulted from severe food shortages, disruption of health services, environmental hazards, and mass population displacement.

\section{Food shortages}

More than 3 million people in former Yugoslavia are dependent upon international food aid, of whom 1.6 million live in Bosnia-Herzegovina (representing $42 \%$ of the current population of 3.8 million). The 380000 citizens of besieged Sarajevo require 270 metric tons of food aid per day; in December, 1992, food aid was providing about 2000 $\mathrm{kcal}(8.5 \mathrm{MJ})$ per person per day, or $75 \%$ of the minimum average winter energy requirements. ${ }^{3}$

Serbian forces have blocked attempts to provide relief to the 150000 or so Muslims living in besieged enclaves in eastern Bosnia and during the first 70 days of 1993, despite every effort by the Office of the United Nations High
Commissioner for Refugees (UNHCR), only 577 metric tons of food reached the enclaves of Srebrenica, Gorazde, and Zepa, and estimated combined needs were over 10 times that amount. In Zepa, food delivered on Feb 17 provided an average of $884 \mathrm{kcal}$ per person per day (one-third minimum requirement) for the 13 days until the next convoy. "Meals-ready-to-eat" retrieved from two American airdrops provided 1 day's additional energy requirements. The convoy that reached Srebrenica on March 19, after the commander of UN Protection Forces established temporary headquarters in the town, contained food that was sufficient for less than 5 days' energy needs for the 60000 inhabitants.

Data collected by the World Health Organization (WHO) from sentinel sites in Bosnia indicate progressive deterioration in nutritional status. ${ }^{4,5}$ By January, 1993, adults had lost between 9 and $15 \mathrm{~kg}$ body weight compared with 1988 levels. The rate of severe chronic energy deficiency (body mass index less than 16) among adults was as high as $15 \%$ (Srebrenik); among children, rates of moderate-tosevere malnutrition (weight-for-age less than $2 \mathrm{SD}$ below reference median) ranged as high as $25 \%$ (Okucani).

The collection of precise mortality data has been difficult because of security concerns and doubts about the reliability of secondary sources. In Zepa, detailed records on deaths were reviewed. Between April, 1992, and March, 1993, about 1190 deaths were recorded among an estimated population of 33000 , equivalent to an annual crude death rate of 36 per 1000 , four times the national death rate reported in Yugoslavia in $1989.0^{6} 57 \%$ of deaths were attributed to "hunger" and $38 \%$ to war-related injuries. Most deaths were reported to have been of young children and old people but an exact age breakdown was not available.

\section{Environmental hazards}

Public water and sanitation systems have been extensively damaged, and the absence of electricity has rendered many municipal pumping systems non-functional. The potential for outbreaks of enterically transmitted disease is high and 


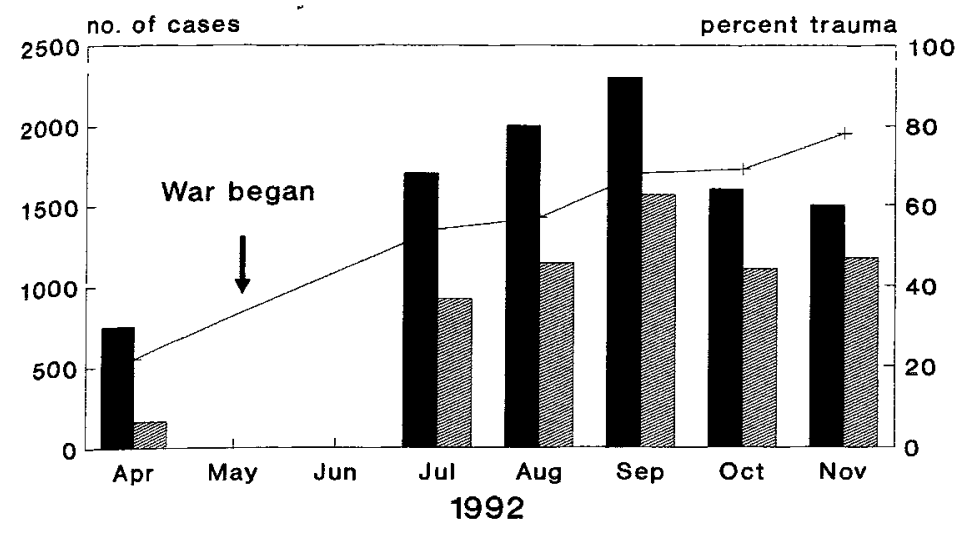

total surgical cases trauma cases

Fig 2-Total surgical admissions and surgical cases associated with trauma, Zenica provincial hospital, Central Bosnia, April to November, 1992.

typically peaks during the summer. The surveillance system established by WHO has so far detected only limited outbreaks of hepatitis, dysentery, and typhoid fever (Dr Tim Healing, personal communciation).

Crowded refugee collectives and detention camps, and general deterioration in hygienic conditions have led to high rates of lice infestation and scabies; ${ }^{7}$ the risk of epidemic louse-borne typhus is high. Rodent populations have increased in some urban areas, heightening the risk of leptospirosis. The incidence of foodborne diseases is likely to increase; brucellosis is a particular threat in the southeastern part of former Yugoslavia, where it is already endemic. The mild winter and the extensive distribution of blankets and sleeping bags appear to have prevented the anticipated high incidence of cold exposure-related health problems.

\section{Collapse of health services}

Medical services in most parts of Bosnia-Herzegovina have been overwhelmed by war casualties. The major hospital in Zenica reported that the proportion of all surgical cases associated with trauma steadily increased during 1992, reaching $78 \%$ in November (fig 2). During February, 1993, the largest hospital in Serb-controlled Bosnia (in Sokolac) reported that war injuries caused two-thirds of all admissions, among whom 35\% were civilians. Preventive health services, including childhood immunisation and antenatal care, have ceased in many areas. Hospitals have also been systematic military targets in some areas, and in Sarajevo, 38 of the city's 42 ambulances have been destroyed. ${ }^{8}$

The collapse of basic health services is illustrated by an increase in the child mortality rate in Zenica province from 20 per 1000 children aged less than 5 years in 1991 to 46 per 1000 in 1992, by a perinatal mortality rate rising from 16 per 1000 live births to 27 per 1000 , and by the proportion of babies with birthweight below $2500 \mathrm{~g}$ increasing from $6 \%$ to $8.7 \%$. Reports suggest that the incidence of newly diagnosed tuberculosis has risen to four times pre-war levels. ${ }^{7}$

Medical supply and distribution systems have collapsed in both Serb and Muslim controlled areas. Most laboratories are not functioning, and many hospitals lack the capacity to test blood for HIV and hepatitis viruses. While large quantities of useful medical supplies have been distributed by WHO, the Red Cross, and nongovernmental organisations, medical staff complained that other donations of medications had either expired or were inappropriate.

\section{Mass displacement}

There are an estimated 810000 refugees and displaced persons in Bosnia-Herzegovina. In central Bosnia, this displacement has exacerbated the strains on medical services; for example, in November, 1992, 37\% of all outpatients in Zenica clinics were displaced persons. About 718000 refugees from Bosnia-Herzegovina have been registered in other republics of former Yugoslavia:

\begin{tabular}{lrcr}
\multicolumn{1}{c}{ Location } & \multicolumn{1}{c}{ From } & From Bosnia- & \\
Croatia & Herzegovina & \multicolumn{1}{c}{ Total } \\
Croatia & 253000 & 288000 & 573000 \\
UN protected areas & 87000 & $\ldots$ & 87000 \\
Serbia & 167000 & 296000 & 463000 \\
Bosnia-Herzegovina & 70000 & 740000 & 810000 \\
Montenegro & 7000 & 57000 & 64000 \\
Slovenia & 2000 & 48000 & 50000 \\
Macedonia & 3000 & 29000 & 32000 \\
Totals & 589000 & 1458000 & 2079000
\end{tabular}

Source: UNHCR, Jan 22, 1993."

Of the 353000 Bosnian refugees in Serbia and Montenegro, $77000(22 \%)$ are Muslims. Almost $95 \%$ of refugees are housed with local host families; the remainder live in collectives. While receiving food rations from UNHCR, refugees rely on local health services. Although international sanctions officially exempt medical supplies, the procurement procedure is complicated and foreign currency is scarce. As the economic situation in Serbia and Montenegro worsens, refugee-hosting families may demand that their guests leave for collective shelters, increasing the number of refugees dependent on international aid and, subsequently, the public health risks associated with refugee camps.

\section{Discussion}

The major public health problem in Bosnia-Herzegovina today is violence directed against civilians on the basis of ethnicity. The impact of the indirect effects of the war has not been fully documented; however, death rates among certain vulnerable groups have increased in some areas, and malnutrition rates are rising. Although epidemics of communicable diseases have so far been averted, environmental conditions and basic health services continue to deteriorate and the potential for severe outbreaks of enterically transmitted, vector-borne, and childhood vaccine-preventable diseases continues to increase.

Primary prevention is the basic strategy of public health, and epidemiology is one of its essential tools. In BosniaHerzegovina, however, epidemiology can be practised safely and reliably in very few areas. Hence, the traditional documentation, monitoring, and evaluation elements of disease prevention may be ineffective. The provision of adequate food, shelter, drinking water, sanitation, and immunisation has proved problematic in a country disrupted by war. In Bosnia-Herzegovina primary prevention means stopping the violence.

Almost a year has passed since this war began; international diplomatic efforts and economic sanctions against Serbia and Montenegro have failed to end it. Current hopes rest on a plan to divide the country into ten ethnic-based autonomous provinces with a weak central government. While this may achieve the short-term goal of diminishing the violence, it is difficult to imagine how public health on a national scale could be effectively revived under a 
plan which will institutionalise ethnic divisions. There may be important public misconceptions about this war, the first being that the Serbs are the only aggressors. Serbian refugees in Montenegro described situations in eastern Herzegovina where Muslim and Croatian forces engaged in "ethnic cleansing". Credible reports have described atrocities committed against civilians on all sides. Food convoys in Bosnia have been obstructed by Croatian as well as Serbian militia. Nor are all Serbs fanatically anti-Muslim; Serbian authorities and Muslim community leaders in Montenegro agreed that most Muslim refugees in that country were being treated well.

It seems unfortunate that international sanctions designed to apply pressure on partisan political leaders may ultimately impact most severely on the health and wellbeing of civilians. Medical supplies and other humanitarian assistance should be exempted from international sanctions. Otherwise, innocent civilians, including refugees from Bosnia-Herzegovina, might inadvertently suffer from the deterioration of health services in Serbia and Montenegro. Public information campaigns employing radio and television programmes beamed from western Europe might be effective in diminishing the climate of hate in BosniaHerzegovina.

There are immediate decisive steps that could be taken to diminish the public health risks; for example, repairing water and sewage systems, restoring medical facilities, increasing the quantity of food delivered to isolated enclaves, strengthening child immunisation programmes, and distributing seeds for spring planting. The establishment of "safe havens" by UN forces and the enforcement of safe passage of refugees would protect some civilians from the violence. Support services are urgently required for women who have experienced sexual violence.

However, we believe that public health will only improve in Bosnia-Herzegovina if the war ends in a way that encourages unity rather than division. The outcome of this war should not serve as a precedent for the violent disintegration of other ethnically diverse nations. If this occurs, recent gains in public health in many parts of the world will be rapidly reversed, a trend that has been observed during a 12-month period in Bosnia-Herzegovina. The traditional tools of public health have not been effective in lessening the impact of the war on the population; therefore, the international public health community needs to actively explore methods for promoting a sustainable peace in the Balkans.

We thank the following individuals for their contributions: Sir Donald Acheson, Michael Benenson, Eric Dachy, Idris Demirovic, Gilbert Despicht, Francois Guiges, Timothy Healing, Judith Kumin, Donatella Linari, Lynellen Long, Miroslav Medic, Melinda Moore, Laila Pasalic, M. Vejzagic, Andrew Vernon, and Ron Waldman.

\section{REFERENCES}

1. Office of US Foreign Disaster Assistance. Situation report no 8. Washington, DC: USAID, 1993.

2. Amnesty International. Bosnia-Herzegovina: rape and sexual abuse by armed forces (Amnesty International report EUR 63/01/93). New York: Amnesty International, 1993.

3. United Nations Administrative Committee on Coordination, Subcommittee on Nutrition, and the International Nutrition Planners Forum. Nutrition in times of disaster. Report of an international conference (Sept 27-30, 1988, Geneva).

4. Robertson A, Travers AJ, Lomax J, et al. Nutrition monitoring in former Yugoslavia. Zagreb: WHO, 1992.

5. World Health Organization. Health monitor for the war affected populations of former Yugoslavia, no 1 (Nov 11, 1992). Zagreb: WHO, 1992.

6. United Nations Children's Fund. The state of the world's children, 1991. New York: UNICEF, 1992

7. Acheson D. Twelfth report from the office of the WHO special representative (Jan 11, 1993). Zagreb: WHO, 1993.

8. Janganjac N. Sarajevo medical report. Sarajevo: UNICEF, 1992

9. UN High Commissioner for Refugees. Information notes on former Yugoslavia. Zagreb: Office of the Special Envoy for Yugoslavia, 1993.

\title{
Life-terminating acts without explicit request of patient ${ }^{\star}$
}

\author{
loes Pijnenborg Paul J. van der maAs Johannes J. M. van Delden \\ CASPAR W. N. LOOMAN
}

In the Dutch nationwide study on medical decisions concerning the end of life (MDEL) lifeterminating acts without the explicit request of the patient (LAWER) were noted in $0.8 \%$ of all deaths. We present here quantitative information and a discussion of the main issues raised by LAWER. In $59 \%$ of LAWER the physician had some information about the patient's wish; in $41 \%$ discussion on the decision would no longer have been possible. In LAWER patients tend to be younger and more likely to be male and to have cancer than in non-acute deaths generally. The physician (specialist or general practitioner) knew the patient on average 2.4 years and 7.2 years, respectively. Life was shortened by between some hours and a week at most in $86 \%$. In $83 \%$ the decision has been discussed with relatives and in $70 \%$ with a colleague. In nearly all cases, according to the physician, the patient was suffering unbearably, there was no chance of improvement, and palliative possibilities were exhausted. MDEL probably will increase in number in future but interviews with Dutch physicians suggest a possible fall in LAWER, even though there will always be some situations in which a well-considered LAWER decision may have to be made.

Lancet 1993; 341: 1196-99.

*Short version of paper to be published in Nederlands Tijdschrift voor Geneeskunde.

ADDRESSES: Department of Public Health, Erasmus University Rotterdam, PO Box 1738, 3000 DR Rotterdam, Netherlands (L. Pijnenborg, MD, Prof P. J. van der Maas, MD, C. W. N. Looman, MSc) and Centre for Bioethics and Health Law, Utrecht University (J. J. M. van Delden, MD). Correspondence to Dr Loes Pijnenborg 